\title{
DER HUND DES DAITSCHIN-TENGRI
}

\author{
Siegbert Hummel
}

Mit 2 Abbildungen

Unter den Darstellungen aus dem lamaistischen Pantheon auf tibetischen und mongolischen Rollbildern (tib.: Thang-ka) findet sich mitunter ein Reiter in kriegerischer Rüstung auf weißem Pferde. In seinem Gefolge entdecken wir stets einen Vogel und einen Hund. Dieser Reiter von weißer Körperfarbe ist der tibetische Dgra-lha, d. h. der die Feinde (besiegende) Gott, der mongolische Kriegsherr Daitschin-Tengri, eine, was Tibet angeht, urspünglich zweifellos vorbuddhistische Gottheit, die ihren Sitz auf der rechten Schulter eines jeden Menschen hat und als Personifizierung der menschlichen Kraft ein mächtiger kriegerischer Beschützer ist. Der Dgra-lha steht dabei mit dem Hüter des Reichtums, des Lebens und der Fruchtbarkeit, dem Nor-lha, der auch als Srog-lha bekannt ist, in engster Beziehung ${ }^{1}$, denn dieser Nor-lha gehört ebenfalls zu den persönlichen Gottheiten.

Beide, sowohl der Dgra-lha oder Daitschin-Tengri als auch der Srog-lha oder Nor-lha, sind die vorbuddhistische Entsprechung anderer, in Tibet später im Gefolge des Lamaismus eingewanderter, Gottheiten des Krieges und des Reichtums. Dabei ist jedoch Daitschin-Tengri, der tibetische Dgra-lha, noch heute ein beliebtes Thema der lamaistischen Ikonographie geblieben, entweder im Verband der berühmten von Dpe [Pe]-dkar [har] angeführten fünf Gesetzeswächter (tib.: Tschos-skyong), zu denen er gehört, oder inmitten von acht Manifestationen seines Wesens, die im Aussehen ganz seiner Gestalt nachgebildet sind (Abb. 1) ${ }^{2}$. Geharnischt und bewaffnet mit Bogen und Pfeilen trägt er in der Linken mitunter einen Speer mit Wimpeln als Banner, während die Rechte ein Schwert oder eine Peitsche, manchmal auch einen Speer schwingt. Mit Pfeil und Bogen, Schwert und Speer, dem Wimpel angebunden sind, ist auch der gepanzerte tibetische Kriegsgott Beg-dse ${ }^{3}$, einer der acht Schrecklichen (tib.: Drag-gsched-brgyad), ausgerüstea. Sind dessen Begleiter die dämonische, nackte Rigs-bu-mo auf dem Löwen und der einen Wolf reitende Srog-bdag, der schon genannte Srog-lha, der zugleich Minister eines der vier Trabanten und Manifestationen des Gottes Dpe-dkar ist, zu denen auch der Dgra-lha gehört, so begegnen wir unter dem Gefolge des Dgra-lha stets einem meist hellfarbenen Hund und einem Vogel, worauf wir bereits eingangs hingewiesen haben. Manchmal sind diese beiden Tiere die einzigen Begleiter.

Der Dgra-lha, Daitschin-Tengri, steht nach diesen kurzen ikonographischen Notizen sowohl mit Dpe-dkar als auch mit Beg-dse in Verbindung, was noch besonders durch die Beziehung des Dgra-lha zum Srog-lha (= Srog-bdag) unterstrichen wird. Auf die Möglichkeit engster, ursprunghafter Beziehungen des kriegerischen Beg-dse und des Wächters der Klosterschätze ${ }^{4}$ Dpe-dkar zu Turkestan und über dieses vielleicht zum Iran hat vor allem Robert Bleichsteiner (1. c.) auf Grund einer Etymologie der Namen ${ }^{5}$ überzeugend hingewiesen. Die außertibetische Herkunft der beiden läßt sich meines Erachtens auch noch an ihrem ikonographischen Bild ablesen und ist zumindest in den Versuch, den fremden Ursprung dieser Gottheiten anzudeuten und kanonisch festzulegen, noch deutlich zu erkennen. Die Aufnahme des Dpe-dkar

1 Vgl. S. Hummel: Geheimnisse tibetischer Malereien, Leipzig 1949, S. 19 f. und Abb. 18. ders.: Ikonographische Notizen zum Lamaismus (in: Jahrb. d. Museums f. Völkerkunde zu Leipzig, Bd. XIII, Leipzig 1954). - R. BleichsteineR : Srog-bdag, der Herr des Lebens (in : Archiv f. Völkerkunde, Bd. V, Wien 1950).

2 Tibetische Miniaturmalerei auf Leinwand, 10:8 cm. Sammlung Günther Schulemann, Dresden.

3 Auch Lcham-sring und Lcham-srang genannt.

4 Auch Dkor-bdag-rgyal-po = Reichtümer besitzender König.

5 Neupers. : Paikar, Mittelpers.: Patkar, Awest.: Paitikara = Idol, Bild; oder Neupers.: Paikâr, Mittelpers.: Patkâr = Krieg, Kampf (vgl. R. Bleichsteiner, l. c.). 
und vielleicht auch des Beg-dse muß spätestens während der Eroberung Turkestans durch die Tibeter vollzogen worden sein, also im 8. Jh. ${ }^{6}$ oder eher noch im 7. Jh., wenn nicht viel früher. Die Legende von der erfolgreichen Verpflichtung Dpe-dkars mit seinen Begleitern, den Rgyal-po-sku-lnga (= Fünf königliche Körper), zu Tschosskyong, also zu Gesetzeswächtern des Buddhismus, und insbesondere der Bericht von der Einsetzung Dpe-dkars zum Hüter der Schatzkammer des Klosters Bsam-yas durch Padmasambhava ist hinreichend bekannt. Etwa zur gleichen Zeit könnte sich, auf Grund verwandter Funktionen im Pantheon, auch die ikonographische Zuordnung des Dgra-lha und des Nor-lha bezw. des Srog-lha [bdag] zu Beg-dse und zu Dpe-dkar angebahnt haben.

Wenn wir bei Beg-dse und Dpe-dkar turkestanische und iranische Ursprünge vermuten, so besteht durchaus auch die Möglichkeit, daß solche im ikonographischen Bild des Dgra-lha anklingen. Umgekehrt könnten dann entsprechende Motive in der Ikonographie des Dgra-lha die Herkunft von Beg-dse und Dpe-dkar weiter aufhellen, da anzunehmen ist, daß außertibetische Elemente, falls diese etwa nach dem Iran weisen sollten, im Zusammenhang mit Beg-dse und Dpe-dkar in die lamaistische Ikonographie und da wieder zunächst in das Bild der mit beiden Gottheiten eng verknüpften Gestalten gekommen sind. Iranische Remiszenzen sehe ich im Hund und im Vogel des Daitschin-Tengri (Abb. 1).

BERNFRIED SchleRATH hat in einer recht beachtlichen Untersuchung ${ }^{7}$ nachgewiesen, daß Hund und Vogel in den religiösen Anschauungen der Indogermanen die Aufgabe eines Seelentieres, eines Seelenträgers verrichten und infolgedessen in der Begleitung von Gottheiten erscheinen, die mit dem Tode, insbesondere mit dem Tode auf dem Schlachtfelde, in Beziehung stehen. Nach iranischen Vorstellungen kommen Hunde den Verstorbenen an der Cinvatbrücke entgegen. Ein Niederschlag dieser Vorstellung findet sich auch im Rigveda $(10,14)$, wonach die Hunde des Totengottes Yama die Seelen zum Totenland geleiten (Schlerath, 1. c., S. 28). Aber auch Odins, des göttlichen Kriegers Hunde sind Todesboten, und so wie nach dem Awesta der Leichenfraß durch Hunde und Vögel den Weg der Seele ins Jenseits sichert, so füttert auf Grund ähnlicher Vorstellungen Odin seine Hunde mit den Leichen der Gefallenen. Die damit verbundene Aufgabe des Hundes kommt offenbar auch den Raben zu, die Odin ständig begleiten, was an die Vögel als Boten des Yama erinnert (Schlerath 1. c., S. 34). Ich will hier nicht auf die Fülle des weiteren Belegmaterials eingehen, das Schleratr anführt. Soweit mir bekannt ist, sind die Bilder mit Daitschin-Tengri und mit einem damit in Zusammenhang stehenden verhältnismäßig seltenen Typ des Kubera die einzigen, auf denen in der lamaistischen Ikonographie Hund und Vogel als unvermeidliches Gefolge einer Gottheit zur Darstellung kommen. Wenn sich auch mitunter eine Affe, manchınal noch außerdem ein Bär, zugesellt, so fehlen doch Hund und Vogel niemals, während der Affe und der Bär, offenbar jüngere ikonographische Zutaten, nicht unbedingt erscheinen müssen ${ }^{8}$.

Auf Abb. $2^{9}$ zeige ich einen Reiter, der den Reichtumsgott Kubera in der soeben erwähnten seltenen Manifestation darstellt. Daß wir es mit einem Bilde Kuberas zu tun haben, dafür bürgt die Juwelenratte im linken Arm. In meiner Untersuchung über «Darstellungen des Reichtumsgottes und des Gottes des Krieges» $\mathbf{1 0}$ habe ich die engen Verbindungen zwischen Kriegsgöttern und Gottheiten des Reichtums, der Fruchtbarkeit und des Lebens, wie sie auch ikonographisch in Erscheinung treten, herausgearbeitet. Die Gestalt auf Abb. 2 ist ganz gewiß mit Vorstellungen vom Dgra-

${ }^{6}$ So nach dem Bericht im Rgyal-rabs-gsal-bai-me-long (vgl. R. Bieichsteiner, l. c.).

7 Der Hund bei den Indogermanen (in: Paideuma, VI, 1, Wiesbaden 1954).

8 Vgl. das von R. Bleichsteiner seiner Arbeit (l. c.) beigegebene Bild des Daitschin-Tengri.

${ }^{9}$ Malerei im Museum f. Völkerkunde zu Leipzig OAs 3576, 34:31 cm; vgl. meine Arbeit „Geheimnisse tibetischer Malereien“, S. 19 f. u. Abb. 17.

${ }^{10}$ Geheimnisse tibetischer Malereien, Kap. I. 

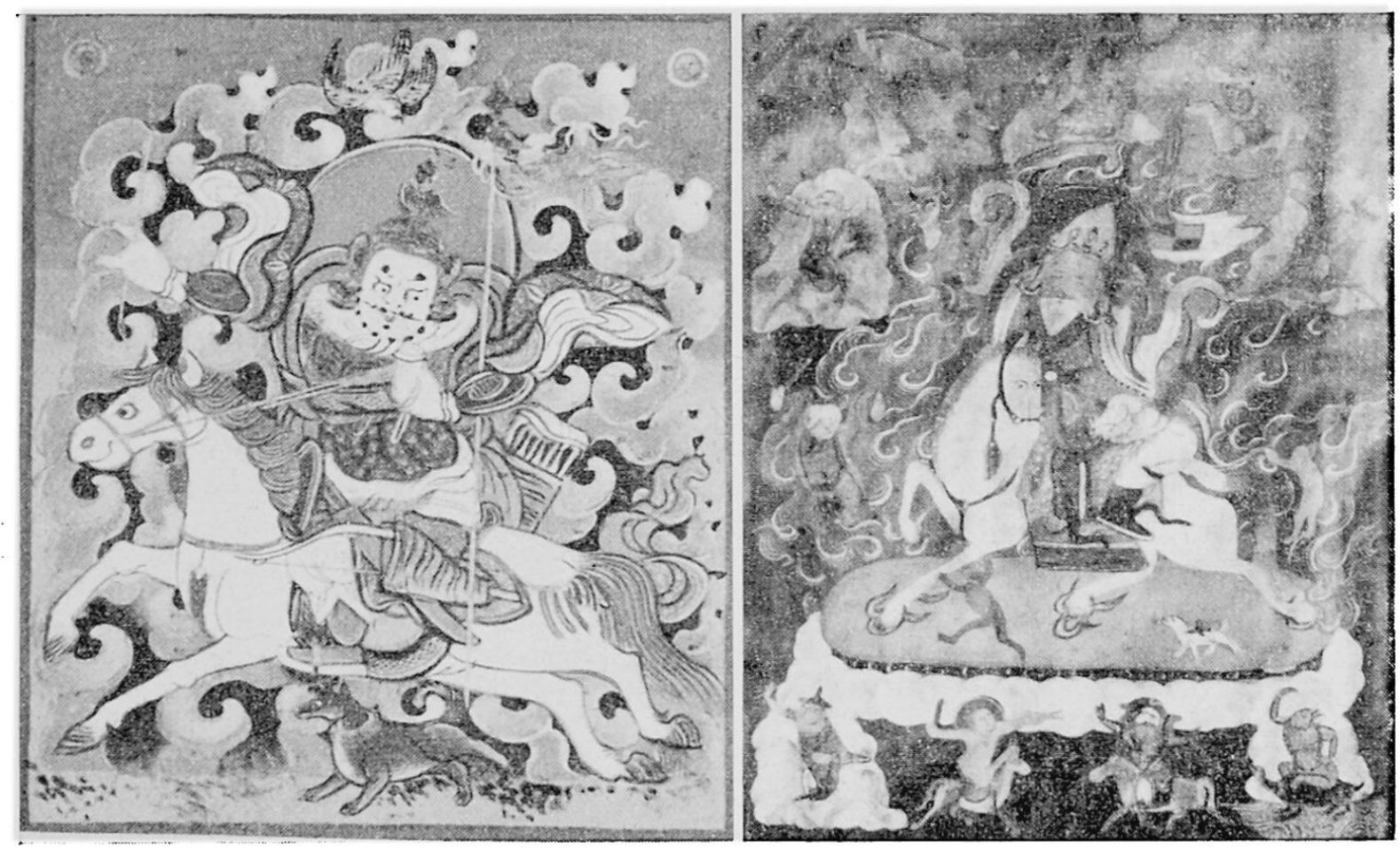

Abb. 1 (links) Tibetische Miniaturmalerei auf Leinwand, 8:10 cm. Sammlung Günther Schulemann, Dresden. Abb. 2 (rechts) Tibetische Malerei im Museum für Völkerkunde zu Leipzig, $31: 34 \mathrm{~cm}$.

lha (Daitschin-Tengri) durchdrungen. Wies ich in der genannten Untersuchung hauptsächlich auf das Gepräge der göttlichen Gestalt hin, so möchte ich jetzt zur Beweisführung das Augenmerk besonders auf das Gefolge lenken, vor allem auf den Hund und auf den Vogel.

Die enge Beziehung von Gottheiten des Reichtums, der Fruchtbarkeit und des Lebens zu solchen des Krieges ist nicht nur in der vorbuddhistischen tibetischen Konzeption der entsprechenden Mitglieder des Pantheons, des Dgra-lha und des Nor-lha bezw. des Srog-lha, gegeben, sondern auch im Sinngehalt des Kriegsgottes Beg-dse mit dem Schätze und Leben spendenden Gefolgsmann Srog-bdag (= Srog-lha) und des Schatzhüters und erfolgreichen Kämpfers gegen die Krankheitsdämonen Dpe-dkar, als dessen Gefolgsmann und Manifestation der Dgra-lha gilt, wie ich oben dargelegt habe. Es kam mir in der genannten Arbeit darauf an, zu zeigen, wie hier, und zwar bereits in vorbuddhistischer Zeit, der Gedanke einer Polarität vorliegen muß. Kubera und der Dgra-lha bezw. Daitschin-Tengri gehen oft kaum entwirrbar ineinander über und werden so zu Aspekten des in Tod und Leben gebundenen Daseins. Nicht nur der fruchtbare, phallizistische, Schätze hütende Yama ist zugleich Totengott, sondern auch der sieghafte Odin, und die Hunde der beiden stehen nach indogermanischen Vorstellungen an der Todesschwelle zwischen zwei Existenzen, wie auch Schlerath (1. c.) gezeigt hat. So erhält die Darstellung sowohl des Kriegsgottes Daitschin-Tengri als auch des diesem verwandten Kubera mit Hund und Vogel als Gefolge ihren tiefen, in das Geheimnis von Tod und Leben reichenden Sinn. Daß die beiden Tiere als Begleiter der genannten Gottheiten in das lamaistische Pantheon aus dem indogermanischen Iran gekommen sind, scheint mir gewiß. Daß bei dieser Einschmelzung die. Berührung mit einer Vorstellungswelt beteiligt war, in der die Ursprünge des Beg-dse und des Dpe [Pe]-dkar [har] und vielleicht auch die der in Tibet allgemein geübten Bestattungsart zum Vogelfraß zu suchen sind ${ }^{11}$, dürfte kaum von der Hand $\mathrm{zu}$ weisen sein.

${ }^{11}$ Vgl. S. Hummel: Nichtanimistisches und Animistisches im Lamaismus. Jahrb. d. Museums f. Völkerkunde zu Leipzig, XIII, 1954. 


\title{
THE DOG OF DAITSCHIN-TENGRI
}

In the Lamaistic Pantheon you see a horseman in a warlike armour, always accompanied by a dog and a bird (Fig. 1). This horseman is the Tibetan Dgra-lha, the Mongolian master of war Daitschin-Tengri, an originally prebuddhistic deity, who is strictly connected to Dpe-dkar as well as to the god of war Beg-dse. The etymology of the names shows the possibility of a former relation of the warlike Beg-dse and the Dpe-dkar, guardian of the monastery treasures, to Turkestan and Iran. From their iconographic features the non-Tibetan origin can easily be recognised. If we take the Turkestanian and Iranian origins for granted in the iconography of Beg-dse and Dpe-dkar, they can appear also in the iconography of Dgra-lha. I see Iranian reminiscences in the dog and the bird of Daitschin-Tengri. According to the religious idea of the Indogermans, dog and bird are soul-animals and consequently they are the attendants of deities who are in relation with death, especially with death on the battle-field. The eating of corpses by dogs and birds - according to the Awesta - prepares the way of the souls into the life to come. On the base of similar ideas, Odin feeds his dogs with the corpses of the dead on the battle-field. Fig. 2 shows the fertile god of wealth Kubera in a unusual manifestation which is in relation with ideas of the martial Dgralha. Kubera and Dgra-lha, i. e. Daitschin-Tengri, often merge into one another, hardly to differenciate and so they become representatives of the existence bound to death and life. Not only the phallicistic Yama is a god of the death, but the victorious Odin too, and the dogs of both are standing on the threshold of death between two existences. So the representation of DaitschinTengri and Kubera with dog and bird has a profound meaning. It is quite clear to me, that both animals attending the mentioned deities has come into the Lamaistic Pantheon from the Indogerman Iran.

\section{LE PROBLÈME DU FLUVIO-GLACIAIRE}

\author{
ADrien JAYET \\ avec 3 figures \\ Introduction
}

La notion de fluvio-glaciaire est si importante que les interprétations concernant la chronologie et les glaciations du Quaternaire en dépendent dans une large mesure. A la suite de recherches dans les différents domaines concernant le Quaternaire j'ai été amené à douter de l'exactitude de l'interprétation actuellement admise, les cailloutis attribués au fluvio-glaciaire ne me semblent pas avoir l'origine que ce terme sous-entend dans son acception actuelle. Par la suite, deux explorations aux glaciers du Valsorey et du Vélan en 1949 et 1950 m'ont apporté une solution satisfaisante. L'essentiel de cette nouvelle interprétation a paru dans les Eclogae geologicae Hielveticae et dans les Archives des Sciences à Genève. En outre un exposé public en a été fait lors de la réunion de la Société suisse de Géomorphologie à Aarau en mars 1954. La présente note est un résumé de cet exposé. Nous remercions le Dr R. Nertz et le Prof. E. WINKLER d'en avoir encouragé la publication.

\section{Le fluvio-glaciaire dans sa conception actuelle}

Différents travaux mais surtout l'œuvre fondamentale de A. PencK et E. BRücKNER 《Die Alpen im Eiszeitalter 》 ont donné les caractéristiques du fluvio-glaciaire. Ce sont des dépôts présentant à la fois des caractères glaciaires, galets striés, blocs, ciment argileux et des caractères fluviatiles, cailloutis, sables et limons sratifiés. La genèse de ces dépôts serait la suivante (fig. 3 ): les torrents issus du front morainique remanient les éléments des moraines (caractères glaciaires) et tendent à les transformer en alluvions (caractères fluviatiles). Vers l'amont le fluvio-glaciaire passe aux moraines frontales et vers l'aval aux alluvions des terrasses. L'ensemble est un complexe fluvio-glaciaire ou cône de transition.

L'idée fondamentale de la conception actuelle réside dans le fait que les dépôts fluvio-glaciaires se seraient formés dans les conditions topographiques actuelles, à par- 